\title{
Effect of Hot-Pressing Temperature on Characteristics of Straw-Based Binderless Fiberboards with Pulping Effluent
}

\author{
Jiajun Wang ${ }^{1,2} \mathbb{C}$, Bo Wang ${ }^{3}$, Junliang Liu ${ }^{1, *}$, Lin $\mathrm{Ni}^{1}$ and Jianzhang $\mathrm{Li}^{2}{ }^{2 *}$ \\ 1 Research Institute of Wood Industry, Chinese Academy of Forestry, Beijing 100091, China; \\ wangjiajun@caf.ac.cn (J.W.); nilin@caf.ac.cn (L.N.) \\ 2 MOE Key Laboratory of Wooden Material Science and Application, Beijing Key Laboratory of Wood Science \\ and Engineering, MOE Engineering Research Centre of Forestry Biomass Materials and Bioenergy, \\ Beijing Forestry University, Beijing 100083, China \\ 3 Tianjin Rongyeda Technology Development Co., Ltd., Tianjin 300384, China; wangbo0035@hotmail.com \\ * Correspondence: liujunliang@caf.ac.cn (J.L.); lijzh@bjfu.edu.cn (J.L.); Tel.: +86-010-62889477 (J.L.); \\ +86-010-62338356 (J.L.)
}

Received: 10 February 2019; Accepted: 12 March 2019; Published: 20 March 2019

\begin{abstract}
This study aimed to improve straw-based fiberboard properties without resins by adding pulping effluent as well as to investigate the difference among boards under variable hot-pressing temperatures. The characterization of fiberboards produced from wheat straw under pressing temperatures ranging from 160 to $200{ }^{\circ} \mathrm{C}$ was first described. The surface appearance, surface chemistry, thermal transitions, and mechanical performance of the boards were evaluated to investigate the effect of varying hot-pressing temperature. The results indicated that the surface color of boards became darker when the temperature was above $190^{\circ} \mathrm{C}$. Additionally, Fourier transform infrared (FT-IR) measurements showed that more low-molecular constituents and hydrogen bonds were produced under higher pressing temperatures. Furthermore, the physical and mechanical property data were analyzed statistically using one-way analysis of variance (ANOVA) and Tukey's tests $(\alpha=0.05)$. The results demonstrated that straw-based fiberboards with effluent under $190^{\circ} \mathrm{C}$ exhibited superior strength and water resistance capacities, and showed great potential in commercial decorating and packaging applications.
\end{abstract}

Keywords: wheat straw; temperature; pulping effluent; self-bonding; fiberboards

\section{Introduction}

Biomass has been brought into focus as a renewable resource in diversiform domains, which is promising for the reduction of carbon emissions and the promotion of cyclic utilization for non-renewable materials. Wheat straw (Triticum aestivum Linn.), which is one of the most abundant agricultural surpluses in the world, has the potential to facilitate price stabilization for sustainable economic development in rural areas. Approximately 175 million tons of dry wheat straw was collected in China in 2015 [1,2]; however, this abundant regenerative resource is not effectively utilized at present. Traditional uses of wheat straw include paper making, acidic sulfite pulping, fiberboard manufacturing, use as feed for animals, and soil conditioning [3-6]. The lack of waste management for this product, combined with the high amount of excess wheat straw, drives the needs for new and high-value applications of such residues. The problem is much more urgent in developing parts of the world, where the direct outdoor burning of superfluous wheat straw is an inevitable fire hazard and causes air pollution. 
As a natural material, wheat straw has been widely used for several decades in the production of fiber and its derivative products. Fiberboards, in combination with fibrous-felted and homogeneous panels, are used for interior door skins, moldings, flooring substrate, and interior trim components. Traditionally, fibers from non-renewable resources are bonded together with adhesives $[7,8]$. However, this process has a number of drawbacks, including the high cost of adhesives [9] and toxic formaldehyde emissions. Omitting the usage of resins in fiberboard manufacturing has the potential to be environmentally friendly and low-cost. Research has been conducted on the production of self-bonding boards using various raw materials [10], including woody and non-woody raw materials. Halvarsson [11] et al. described the straw fibers as a low-budget starting material for binder-free fiberboard. For the purpose of reinforcing fiber interlacing to a level of ideal performance, Fenton's reagent [12], enzymatic additives [13,14], and other additives [15-17] have also been used for pretreating raw materials [9]. Combined with these additives, pressing temperature is one of the most important factors influencing panel characteristics. A higher pressing temperature results in the emission of extractives [18,19], and the mechanical properties of panels can be controlled by various temperature intervals. Chemical changes with temperature variations can contribute to self-bonding, and the reduction of water absorption also results from the degradation of hemicelluloses [20]. The physical-mechanical performance of binderless boards made from sugarcane bagasse were modified by increasing the pressing temperature according to Okuda [21]. Chow et al. [22] manufactured boards without an adhesion agent by using Douglas fir (Pseudotsuga menziesii) bark, in which thermocompression under a high pressing temperature range of $200-300{ }^{\circ} \mathrm{C}$ was applied instead of steam treatment, and demonstrated that it was effective to manufacture binderless board under a higher temperature range to enhance the product quality without additional processing. However, it was determined that temperatures should be limited to within $200{ }^{\circ} \mathrm{C}$ in order to avoid darkening, which affects the surface appearance of boards.

Adding pulping effluent as an adhesive not only simplifies the fabrication process, but also drives the cost down during fiberboard production [23]. Pulping effluent is always produced in the process of fiber manufacturing and papermaking, and is a complex mixture of inorganic and organic matter mainly containing lignin and polysaccharide [24]. A substantial amount of wastewater also needs to be treated in this process, since the water causes high chemical oxygen demand (COD) and becomes dark in color, with lignin and phenolic substances present [25]. However, these elements are critical for adhesion between fibers [26]. Thereby, the valorization of wheat straw and pulping effluent as a binder could utilize the resources efficiently and contribute to the worldwide zero waste strategy. Currently, effluent is still underutilized due to its inherent complexity and inefficiency [27], which makes it difficult to be recycled for industrial production. The bonding mechanism of straw-based fiberboards with pulping effluent therefore requires further study. In our previous work [23], the properties of the boards with variable amounts of pulping effluent were investigated, but gaps in knowledge remain concerning the effect of temperature towards the properties of straw-based fiberboards without adhesive but with the addition of pulping effluent.

Here, this study aims to manufacture fiberboards using wheat straw by adding pulping effluent instead of synthetic binders with different hot-pressing temperatures, and to investigate the effect of temperature on the properties of straw-based fiberboards.

\section{Materials and Methods}

\subsection{Materials}

The wheat straw, pulping fibers, and pulping effluent used in this study were supplied by Tianjin Rong Yeda Fiber Technology Co., Ltd., in Tianjin, China. The pulp was passed through a defibrator by alkaline, and the straw and pulp were air-dried for three days at room temperature before testing. Pulping effluent was dried by lyophilization (LJC-10C; Four-ring, Beijing, China) for $48 \mathrm{~h}$. 


\subsection{Main Chemical Components}

Wheat straw and pulp fibers were milled into 40-60 mesh of powder by a plant mill. The cellulose [28], ash [29], extractive [30-32], and Klason lignin [33] content were then determined. The $\mathrm{pH}$ of the pulping effluent was measured by a LEICI PHS-3C (LEICI, Shanghai, China) and a Shimadzu UV-2600 spectrometer (Shimadzu, Kyoto, Japan) was used to determine the content of protein according to the method of Waddel [34].

\subsection{Straw-Based Fiberboard Production}

The pulp fibers were mixed with $10 \mathrm{wt}$.\% pulping effluent. The boards were shaped from the mixture manually using a forming box $(300.0 \mathrm{~mm} \times 300.0 \mathrm{~mm})$, with a target thickness of $1.5 \mathrm{~mm}$ and a target density of $1000 \mathrm{~kg} / \mathrm{m}^{3}$. After the boards were shaped, the mats were dried to $30 \%$ moisture content and pressed at a pressure of $7.5 \mathrm{MPa}$ for $4 \mathrm{~min}$ under different temperatures $(160,170,180,190$, and $200^{\circ} \mathrm{C}$ ) in triplicates. Meanwhile, three panels without pulping effluent were produced under $180^{\circ} \mathrm{C}$ as the blank control group. After the thermomechanical process, all specimens were stored in a conditioning chamber at $20{ }^{\circ} \mathrm{C}$ with a relative humidity of $65 \%$ to reach an equilibrium state.

\subsection{Fourier Transform Infrared (FT-IR)}

The Fourier transform infrared (FT-IR) analyses were conducted using a Nicolet Spectrometer IS10 (Nicolet, Madison, WI, USA) to identify the structural changes of the functional groups under a variable hot-pressing temperature. Prior to the analysis, the specimens were ground and mixed with potassium bromide (KBr). All spectra were collected in the wave number range between 3000 and $400 \mathrm{~cm}^{-1}$, with dots per inch (DPI) of $4 \mathrm{~cm}^{-1}$ and at least 32 scans of each specimen.

\subsection{Thermo Gravimetric Analyses (TGA)}

The wheat straw and boards were processed by thermo gravimetric analyses (TGA). Thermal transitions were measured by TA Instruments Q100 TGA (TA Instruments, New Castle, DE, USA), at a heating rate of $10^{\circ} \mathrm{C} / \mathrm{min}$ under nitrogen with a $20 \mathrm{~mL} / \mathrm{min}$ flow rate. The samples were heated from ambient temperature to $750{ }^{\circ} \mathrm{C}$.

\subsection{Physical and Mechanical Characterization}

The modulus of elasticity (MOE), modulus of rupture (MOR), water absorption (WA), thickness swelling (TS), and internal bonding strength (IB) of the fiberboards were measured for each specimen, according to Chinese standards [35]. MOE and MOR were measured by three-point static bending tests on specimens with dimensions of $150.0 \mathrm{~mm} \times 50.0 \mathrm{~mm} \times 1.5 \mathrm{~mm}$ at a crosshead speed of $5 \mathrm{~mm} / \mathrm{min}$ using Instron 5582 (Instron, Grove, PA, USA). IB was also measured by pulling the specimens $(50.0 \mathrm{~mm} \times 50.0 \mathrm{~mm} \times 1.5 \mathrm{~mm})$ apart in a perpendicular direction using Instron 5582 . The mass and thickness of specimens with dimensions of $50.0 \mathrm{~mm} \times 50.0 \mathrm{~mm} \times 1.5 \mathrm{~mm}$ were measured before and immediately after the $24 \mathrm{~h}$ soaking process at $20^{\circ} \mathrm{C}$, and WA and TS refer to the percentage increase in the mass and thickness of a specimen, respectively. Each operation was performed in six replicates, and the mean value with standard deviation (SD) was calculated. A one-way analysis of variance (ANOVA) was applied to examine the effects of hot-pressing temperature on the properties of the boards. A Tukey's test $(\alpha=0.05)$ was used to determine which groups were significantly different from one another. All statistical analyses were operated using IBM SPSS Statistical Version 22.0 (IBM, Armonk, NY, USA). 


\section{Results and Discussion}

\subsection{Surface Appearance}

The manufactured fiberboards exhibited smooth surfaces [36], and the degree of surface darkening (Figure 1) with evaluated treatment temperature corresponded well with previous research [37]. This benefited primarily from the chemical modification of the wood constituents and the transference of the extractives [37]. According to other studies, the intensity of thermal degradation was directly related to the intensity of surface darkening, and was explained by hemicellulose hydrolysis and an increase in acid-insoluble lignin [38]. Similar fiberboards have been produced from unripe coconut husks, with high levels of hydrolysis in the biomass and the modification of chemical components in the process of hot pressing [39].
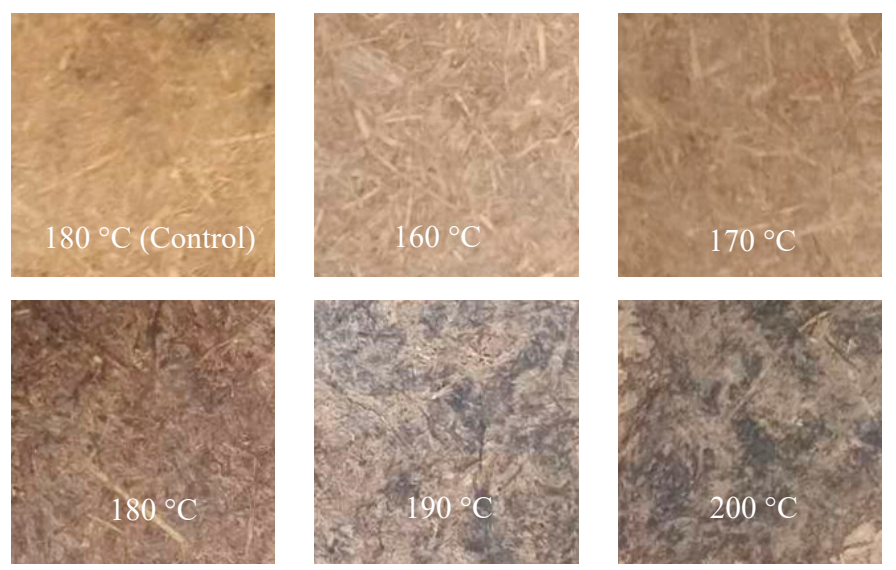

Figure 1. Photographs of fiberboards produced at different temperatures.

\subsection{Chemical Characterization}

Previous studies have demonstrated that lignin, as well as other carbohydrate substances, i.e., sugar and starch, are potential chemical constituents contributing to the bonding of fibers [16,40]. The chemical compositions of wheat straw and pulp are listed in Table 1 . The wheat straw contains abundant $\alpha$-cellulose $(55.68 \%)$, providing several valorization opportunities in preparing fiberboards. In our previous work [23], the chemical composition of pulp fibers revealed moderate lignin and low ash contents. As a result, wheat straw could be used as an alternative low-cost material to manufacture fiberboards paralleling those acquired using milled wood according to Migneault et al. [41] and Mancera et al. [42]. In the comparison of wood resources, straw contains a smaller amount of additional secondary components, such as extractives, in addition to cellulose, hemicellulose, and lignin. Analogous results have also reported the use of other agricultural materials to create fiberboards without supplement, such as white coir and pith ( $\alpha$-cellulose: 27.0\%, 23.0\%; Klason lignin: 38.7\%, 41.1\%) [39]. Additionally, the extractives generated by tannins, oligosaccharides, and aromatics are potentially rich in pulping fiber, and conducive to forming phenolic bridges between lignin and carbohydrates (lignin-carbohydrate complexes (LCCs)). These bonds could enhance the mechanical capacities of straw-based boards with mechanical entanglement through the softened lignin molecules under hot pressing. Lignin and protein in the pulping effluent (Table 2) had a positive effect on the mechanical properties of boards, as demonstrated in previous studies concerning the application of lignin and proteins in adhesive formulas [43-45]. Furthermore, the formulation with $30 \mathrm{wt}$ \% black liquor mostly conformed to the requirements of Chinese standards for medium density fiberboards. Due to the glass transition temperature of around $90{ }^{\circ} \mathrm{C}$ and the melting point of approximately $170{ }^{\circ} \mathrm{C}$ [46], lignin should be considered a thermoplastic material that becomes soft in the presence of heat and humidity [44]. Consequently, pressing temperature is a key parameter in the preparation process. 
Table 1. Chemical compositions of wheat straw and pulp fibers.

\begin{tabular}{|c|c|c|c|c|c|c|c|c|}
\hline \multirow[b]{2}{*}{ Characteristics } & \multirow[b]{2}{*}{ Ash (\%) } & \multirow{2}{*}{$\begin{array}{c}\alpha \text {-Cellulose } \\
(\%)\end{array}$} & \multirow{2}{*}{$\begin{array}{c}\text { Holocellulose } \\
(\%)\end{array}$} & \multirow{2}{*}{$\begin{array}{l}\text { Lignin } \\
(\%)\end{array}$} & \multicolumn{4}{|c|}{ Extractives (\%) } \\
\hline & & & & & $\begin{array}{c}\text { Cold } \\
\text { Water }\end{array}$ & $\begin{array}{c}\text { Hot } \\
\text { Water }\end{array}$ & $\begin{array}{c}1 \% \\
\mathrm{NaOH}\end{array}$ & Alcohol-Benzene \\
\hline Pulping fibers & 5.97 & 35.71 & 36.75 & 11.18 & 40.78 & 49.54 & 51.43 & 3.97 \\
\hline
\end{tabular}

Table 2. Chemical composition of pulping effluent.

\begin{tabular}{cccccccc}
\hline Characteristics & $\mathrm{pH}$ & $\begin{array}{c}\text { Density } \\
(\mathrm{g} / \mathrm{mL})\end{array}$ & $\begin{array}{c}\text { Dissolved Solids } \\
\text { Concentration } \\
(\mathbf{g} / \mathrm{L})\end{array}$ & $\begin{array}{c}\text { Extractive } \\
\left(\begin{array}{c}\text { Alcohol-Benzene) } \\
(\mathbf{\%})\end{array}\right.\end{array}$ & $\begin{array}{c}\text { Ash } \\
(\mathbf{m g} / \mathbf{m L})\end{array}$ & $\begin{array}{c}\text { Lignin } \\
(\mathbf{m g} / \mathbf{m L})\end{array}$ & $\begin{array}{c}\text { Protein } \\
(\mathbf{m g} / \mathbf{m L})\end{array}$ \\
\hline Values & 9.17 & 1.00 & 17.50 & 0.09 & 752 & 190 & 2.95 \\
\hline
\end{tabular}

\subsection{Imaging FT-IR Spectra}

Functional group analysis of the FT-IR spectrogram was based on the work of George and Mclntyre [47]. The FT-IR spectra bands were predominantly assigned to cellulose, hemicellulose, and lignin, which are the major components of straw wheat. The IR spectra of the raw materials, controlled fiberboards, and boards with effluent under different hot-pressing temperatures are illustrated in Figure 2. The results of the FT-IR showed two special sections (not presented) that could be identified: (i) the functional section in the $3800-2700 \mathrm{~cm}^{-1}$ range, assigned to different $\mathrm{C}-\mathrm{H}$ stretching vibration groups and $\mathrm{O}-\mathrm{H}$ stretching absorption [48], and (ii) the fingerprint section, from $1800-800 \mathrm{~cm}^{-1}$, assigned to different stretching or bending vibrations of the functional groups of biomass components. After hot-pressing treatment, several significant changes in peak intensity could be observed in the spectra of fiberboards at 1739, 1376, 1335, 1319, 1241, 1162, 1110, and $900 \mathrm{~cm}^{-1}$. Absorbance bands with the wave numbers of $1000-1200 \mathrm{~cm}^{-1}$ were characteristic of $\mathrm{C}-\mathrm{O}$ vibration of cellulose and xylan. With the increase of temperature, there was a shift of the $\mathrm{C}-\mathrm{O}$ carbonyl band at $1739 \mathrm{~cm}^{-1}$ and the $\mathrm{C}-\mathrm{O}$ absorption band at $1241 \mathrm{~cm}^{-1}$. This finding indicated that more hemicellulose was hydrolyzing, and that there was an increase in the hydrolysis of aldehyde compounds such as hydroxymethylfurfural and furfural. Recently, some researches have demonstrated that the characteristics of lignin as a plastic material could improve the mechanical performance of binder-free fiberboards [19,49-51]. The initial lignin content of the boards at different pressing temperatures were mostly identical to that shown in Table 1; as such, it was reasonable to assume it would display almost the same peak intensity at $1511 \mathrm{~cm}^{-1}$, derived from the aromatic units in lignin. Consequently, the peak at $1511 \mathrm{~cm}^{-1}$ was used as a constant standard to derive the relative absorbance of fiberboards with effluent, which differed from the boards without effluent and raw materials. Furthermore, the spectra at 1376, 1162, and $900 \mathrm{~cm}^{-1}$ were more significant under higher hot-pressing temperatures. The change at $1162 \mathrm{~cm}^{-1}$ was supposed to generate new ether linkages resulting from the reaction between hemicellulose by-products and lignin during the hot-pressing process, which was the lignin-carbohydrate complex (LCC). The increased intensity at 1376 and $900 \mathrm{~cm}^{-1}$ could be attributed to the polymerization of glycosidic components among low-molecular carbohydrates [52]. These linkages could enhance the self-bonding strength of boards without adhesion. The effluent also contained proteins, as shown in Table 2. The main vibration bands of the proteins were at 3300, 3100, 1690-1600, 1575-1480, 1301-1229, 767-625, 800-640, 606-537, and $200 \mathrm{~cm}^{-1}$. However, the typical vibration bands were not identified in overlapping sludge spectra [53]. Overall, the differences among the FT-IR spectra of samples at varying pressing temperatures were not significant. This result suggested that the chemical changes that occurred were either few or infrared-inactive during the hot-pressing process. 


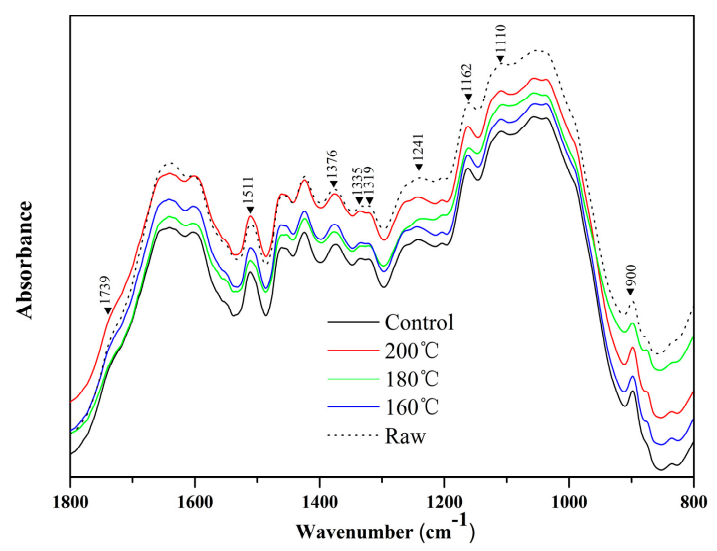

Figure 2. Fourier transform infrared (FT-IR) spectra of wheat straw and fiberboards produced at different temperatures.

\subsection{Thermal Stability}

The thermogravimetric properties of the blank control group and different board types under diverse hot-pressing temperatures are provided in Figure 3 as mass loss curves. Table 3 presents a selection of the specimen thermal properties, where each specimen was measured twice. The thermal behavior of fiberboards is relevant in the determination of process conditions for binderless board production. The curves depict three steps, and the main mass loss was between temperature levels of 200 and $300{ }^{\circ} \mathrm{C}$. This mass loss could be due to the thermal decomposition of water-soluble components, hemicellulose, and a portion of cellulose. The board panels under $200{ }^{\circ} \mathrm{C}$ had the highest temperature for the mass loss of $10 \%$, and lowest mass loss compared to boards with pulping effluent. Approximately $52.79 \%$ of samples pressed at $200{ }^{\circ} \mathrm{C}$ were degraded at a temperature below $500{ }^{\circ} \mathrm{C}$, which was the least among all specimens. This finding was also supported by Lee et al. [54], who found that the minimum thermal decomposition rates for major sugars, including sucrose, glucose, and fructose, were at 138, 150 , and $107^{\circ} \mathrm{C}$, respectively. There were two factors contributing to this trend. The first factor was the fragmentation of polysaccharides [55]; it was well understood that the removal of extractives and the fragmentation of hemicellulose and lignin all took place at high temperatures, and this result also corresponded well with the FT-IR analysis. On the other hand, the thermomechanical process, along with steam, was caused by the $30 \%$ moisture content of the slab as well as the presence of $\mathrm{OH}$ groups between fiber interfaces. In addition, the temperature for $10 \%$ mass loss of control boards was slightly higher than that of boards with effluent, and the total mass loss was reduced. As a possible reason for this outcome, it could be presumed that thermal softening of lignin played an important role in board performance expression. Thermal softening changes could involve glass transition because the local temperature of the board during hot pressing and the local glass transition temperature $\left(T-T_{\mathrm{g}}\right)$ value were reported to correlate to the mechanical performance of the boards $[56,57]$.

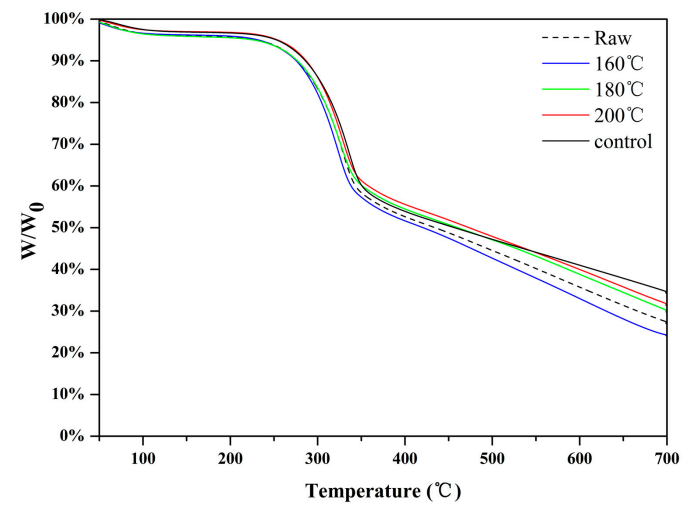

Figure 3. Pyrolysis curves of wheat straw and fiberboards produced at different temperatures. 
Table 3. Thermal properties of wheat straw and fiberboards produced at different temperatures.

\begin{tabular}{cccccc}
\hline Specimens & $\begin{array}{c}\text { Onset Mass } \\
(\mathbf{m g})\end{array}$ & $\begin{array}{c}\text { Temperature for the } \\
\left.\text { Mass Loss of } \mathbf{1 0} \% \mathbf{( ~}^{\circ} \mathbf{C}\right)\end{array}$ & $\begin{array}{c}\text { Mass Loss at } \\
\mathbf{T} \leq \mathbf{5 0 0}{ }^{\circ} \mathbf{C ~ ( \% )}\end{array}$ & $\begin{array}{c}\text { Final Mass } \\
(\mathbf{m g})\end{array}$ & $\begin{array}{c}\text { Total Mass } \\
\text { Loss } \mathbf{( \% )}\end{array}$ \\
\hline Raw & 8.38669 & 270.34 & 55.96 & 2.26536 & 72.99 \\
$160^{\circ} \mathrm{C}$ & 6.59972 & 271.31 & 59.23 & 1.59229 & 75.87 \\
$180{ }^{\circ} \mathrm{C}$ & 8.92963 & 270.01 & 53.40 & 2.64878 & 70.34 \\
$200{ }^{\circ} \mathrm{C}$ & 8.61852 & 277.82 & 52.79 & 2.68206 & 68.88 \\
Control $\left(180^{\circ} \mathrm{C}\right)$ & 13.75989 & 277.32 & 53.33 & 4.69269 & 65.90 \\
\hline
\end{tabular}

\subsection{Physical-Technological Properties of Fiberboards}

Table 4 describes the mean values and standard deviations of physical-technological properties, using ANOVA and Tukey's test results. Values followed by identical lowercase superscripted letters $(a, b$, and $c)$ indicate no statistical differences $(p>0.05)$. The MOR, MOE, TS, WA, and IB of the straw-based binderless fiberboards were improved by adding effluent, in comparison with the control fiberboard. Similar improvements in mechanical properties due to the treatment process were observed in a previous study [23]. However, the difference of this study from others was that boards with different densities were produced and the densification produces enhanced the board mechanical capacities. The results (Table 4) in this study showed that the mechanical properties of fiberboard samples were significantly influenced by the pressing temperature $(p<0.01)$. The Tukey's test indicated that there was no remarkable difference in the physical-technological properties when increasing the temperature from 160 to $170{ }^{\circ} \mathrm{C}$, except the TS. Nevertheless, there was a statistically significant difference in the range of 180 to $200{ }^{\circ} \mathrm{C}$. The TS and WA of the boards decreased with an increase of the pressing temperature, reaching a minimum value $\left(28.0 \%\right.$ and $80.2 \%$, respectively) at $200{ }^{\circ} \mathrm{C}$ (Table 4$)$. This tendency was expected since high temperatures promoted the exudation of extractives, as well as a more hydrophobic surface of boards [58]. The boards pressed at $190^{\circ} \mathrm{C}$ exhibited the highest MOR of $20.16 \mathrm{MPa}$, the highest MOE of $2994 \mathrm{MPa}$, and the higher IB of $1.02 \mathrm{MPa}$. The MOR, MOE, and IB of boards at $190{ }^{\circ} \mathrm{C}$ were $56.60 \%, 71.38 \%$, and $29.11 \%$, respectively, higher than those obtained at $160{ }^{\circ} \mathrm{C}$. Therefore, binderless fiberboards from wheat straws and pulping effluent were found to reach the Chinese standard GB/T 21723 [59], except for the TS (MOR $\geq 14 \mathrm{MPa}, \mathrm{MOE} \geq 1800 \mathrm{MPa}, \mathrm{IB} \geq 0.45 \mathrm{MPa}$ ). Similar straw-based boards using steam explosion were produced by Luo et al. [60], and their experiments verified that binderless spruce and pine fiberboards had better water resistance than those made from wheat straw. The straw-based binderless fiberboards are not the final product, however, and can be further utilized after coating with a waterproof membrane. In such a case, the products would be used in normal climate conditions. In addition to temperature, it is suggested that one possible way to further improve adhesion is to chemically activate lignin in the effluent, by using enzymatic hydrolysis treatment so that the binding between fibers can be promoted during hot pressing.

Table 4. The mean values and standard deviations of physical-technological properties, obtained using one-way analysis of variance (ANOVA) and Tukey's test results.

\begin{tabular}{|c|c|c|c|c|c|}
\hline Groups & $\begin{array}{c}\text { Modulus of } \\
\text { Rupture } \\
\text { (MOR) (MPa) }\end{array}$ & $\begin{array}{l}\text { Modulus of } \\
\text { Elasticity } \\
\text { MOE (MPa) }\end{array}$ & $\begin{array}{c}\text { Thickness } \\
\text { Swelling (TS) } \\
(\%)\end{array}$ & $\begin{array}{c}\text { Water } \\
\text { Absorption } \\
\text { (WA) (\%) }\end{array}$ & $\begin{array}{c}\text { Internal Bonding } \\
\text { Strength (IB) } \\
\text { (MPa) }\end{array}$ \\
\hline Control $\left(180{ }^{\circ} \mathrm{C}\right)$ & $16.4 \pm 2.0$ & $1914 \pm 158$ & $33.3 \pm 3.2$ & $95.0 \pm 5.1$ & $0.84 \pm 0.07$ \\
\hline $160^{\circ} \mathrm{C}$ & $15.9 \pm 1.5^{b}$ & $1747 \pm 124^{b}$ & $33.9 \pm 2.7^{\mathrm{a}}$ & $99.1 \pm 4.7^{\mathrm{a}}$ & $0.79 \pm 0.04^{\mathrm{c}}$ \\
\hline $170^{\circ} \mathrm{C}$ & $17.5 \pm 1.2^{b}$ & $2046 \pm 480^{b}$ & $32.8 \pm 1.5^{\mathrm{ab}}$ & $95.3 \pm 5.9^{a}$ & $0.81 \pm 0.06^{\mathrm{c}}$ \\
\hline $180^{\circ} \mathrm{C}$ & $21.2 \pm 1.6^{b}$ & $2892 \pm 207^{a}$ & $31.1 \pm 1.0^{\mathrm{abc}}$ & $91.4 \pm 6.4^{\mathrm{ab}}$ & $0.90 \pm 0.03^{b c}$ \\
\hline$p$-level & $0.000 *$ & $0.000 *$ & $0.000 *$ & $0.000 *$ & $0.000 *$ \\
\hline Straw-based wood [60] & 18.10 & - & - & 63.7 & 0.24 \\
\hline Spruce and pine residues [16] & 22.5 & 5000 & 18 & 45 & 0.75 \\
\hline
\end{tabular}

Different uppercase letters in each row and lowercase letters in each column depict statistical differences $(p<0.05)$.

“*” means significantly different at $p<0.01$. 


\section{Conclusions}

This work investigated the properties of manufactured straw-based fiberboards without resin under different hot-pressing temperatures. The chemical composition of pulp revealed moderate lignin and low ash contents, which could be used as an alternative low-cost source to manufacture fiberboards. Fiberboards without synthetic adhesive were prepared by hot-pressing mixtures of pulp and effluent at $160-200{ }^{\circ} \mathrm{C}$. The pulping effluent content was tested, and the mechanical performance of boards pressed under various temperatures was determined. The FT-IR curves suggested that the proteins and lignin in the effluent were beneficial in creating new covalent bands under higher thermal-pressing temperatures, and thus showed better MOR, TS, and IB performances. Nevertheless, with a pressing temperature higher than $190^{\circ} \mathrm{C}$, the color of the boards became dark and there was excess energy consumption. There was no significant difference at $160-170^{\circ} \mathrm{C}$, or when the pressing temperature reached up to $190{ }^{\circ} \mathrm{C}$. The properties of the straw-based fiberboards were improved significantly, illustrating that pulping effluent can be used as an adhesive. It is suggested that further studies be conducted in relation to activating lignin in effluent water before this technology can be implemented commercially.

Author Contributions: Conceptualization, J.W. and J.L. (Junliang Liu); Methodology, J.W. and L.N.; Formal Analysis, J.W.; Resources, B.W.; Data Curation, J.W. and L.N.; Writing-Original Draft Preparation, J.W.; Writing-Review \& Editing, J.W. and L.N.; Supervision, J.L. (Junliang Liu) and J.L. (Jianzhang Li); Project Administration, J.L. (Junliang Liu).

Funding: This research received no external funding.

Acknowledgments: The technical guidance from the research Institute of Wood Industry, Chinese Academy of Forestry is gratefully acknowledged. The authors would also like to thank Tianjin Rongyeda Technology Development Co., Ltd., for supplying the raw materials.

Conflicts of Interest: The authors declare no conflict of interest.

\section{References}

1. Zhou, X.; Wang, F.; Hu, H.; Yang, L.; Guo, P.; Xiao, B. Assessment of sustainable biomass resource for energy use in China. Biomass Bioenerg. 2011, 35, 1-11. [CrossRef]

2. Wang, X.; Yang, I.; Steinherger, Y.; Liu, Z.; Liao, S.; Xie, G. Field crop residue estimate and availability for biofuel production in China. Renew. Sust. Energ. Rev. 2013, 27, 864-875. [CrossRef]

3. Doyle, C.J.; Mason, V.C.; Baker, R.D. Straw disposal and utilization: An economic evaluation of the alternative end-uses for wheat straw in the UK. Biol. Wastes 1988, 23, 39-56. [CrossRef]

4. Zhang, P.; Wei, T.; Jia, Z.; Han, Q.; Ren, X.; Li, Y. Effects of straw incorporation on soil organic matter and soil water-stable aggregates content in semiarid regions of Northwest China. PLoS ONE 2014, 9, e92839. [CrossRef] [PubMed]

5. Xie, L.; Liu, M.; Ni, B.; Wang, Y. Utilization of wheat straw for the preparation of coated controlled-release fertilizer with the function of water retention. J. Agric. Food Chem. 2012, 60, 6921-6928. [CrossRef] [PubMed]

6. Xie, W.; Zhang, Y.; Wu, T.; Wu, L.; Li, X.; Ouyang, Z. Effects of straw application on coastal saline topsoil salinity and wheat yield trend. Soil Tillage Res. 2017, 169, 1-6. [CrossRef]

7. Galperin, A.S.; Kuleshov, G.G.; Tarashkevich, V.I.; Shutov, G.M. Manufacturing and properties of modified wood: A review of 25 years work. Holzforschung 1995, 49, 45-50. [CrossRef]

8. Ghaffar, S.H.; Fan, M. Differential behavior of nodes and internodes of wheat straw with various pre-treatments. Biomass Bioenergy 2015, 83, 373-382. [CrossRef]

9. Nitu, I.P.; Shams, M.; Islam, M.; Ratul, S.B.; Ashaduzzaman, M. Development of binderless composites from different nonwood lignocellulosic materials: Overview. In Handbook of Ecomaterials; Martínez, L., Kharissova, O., Kharisov, B., Eds.; Springer: Cham, Switzerland, 2018.

10. Jain, S.K.; Handa, S.K. Press for producing binderless board from agricultural waste. Res. Ind. 1982, 27, 121-123.

11. Halvarsson, S.; Edlund, H.; Norgren, M. Manufacture of non-resin wheat straw fiberboards. Ind. Crop. Prod. 2009, 29, 437-445. [CrossRef] 
12. Mejía, E.H.; Quintana, G.C.; Ogunsile, B.O. Development of binderless fiberboards from steam exploded and oxidized oil palm wastes. BioResources 2014, 9, 2922-2936. [CrossRef]

13. Euring, M.; Trojanowski, J.; Horstmann, M.; Kharazipour, A. Studies of enzymatic oxidation of TMP fibers and lignin model compounds by a laccase-mediator-system using different $14 \mathrm{C}$ and $13 \mathrm{C}$ techniques. Wood Sci. Technol. 2011, 46, 699-708. [CrossRef]

14. Kudanga, T.; Nyanhongo, G.S.; Guebitz, G.M.; Burton, S. Potential applications of laccase-mediated coupling and grafting reactions: A review. Enzyme Microb. Tech. 2011, 48, 195-208. [CrossRef] [PubMed]

15. El Mansouri, N.E.; Pizzi, A.; Salvado, J. Lignin-based polycondensation resins for wood adhesives. J. Appl. Polym. Sci. 2007, 103, 1690-1699. [CrossRef]

16. Anglès, M.N.; Ferrando, F.; Farriol, X.; Salvadó, J. Suitability of steam exploded residual softwood for the production of binderless panels. Effect of the pre-treatment severity and lignin addition. Biomass Bioenerg. 2001, 21, 211-224. [CrossRef]

17. Zhou, X.; Zheng, F.; Lv, C.; Tang, L.; Wei, K.; Liu, X.; Du, G.; Yong, Q.; Xue, G. Properties of formaldehyde-free environmentally friendly lignocellulosic composites made from poplar fibres and oxygen-plasma-treated enzymatic hydrolysis lignin. Compos. Part B Eng. 2013, 53, 369-375. [CrossRef]

18. Álvarez, C.; Rojano, B.; Almaza, O.; Rojas, O.J.; Gañán, P. Self-bonding boards from plantain fiber bundles after enzymatic treatment: Adhesion improvement of lignocellulosic products by enzymatic pre-treatment. J. Polym. Environ. 2011, 19, 182-188. [CrossRef]

19. Fahmy, T.Y.A.; Mobarak, F. Advanced self-bonded board-like green nanocomposites from undebarked cotton stalks and mechanism of self-bonding. Cellulose 2013, 20, 1453-1457. [CrossRef]

20. Cao, Z.; Yan, H.; Guo, W. Study on bonding mechanism of dry-process self-bonded fiberboards part I. Chemical changes and effects in self-bonded fiberboard manufacture. China Wood Ind. 1996, 5, 3-6. (In Chinese)

21. Okuda, N.; Sato, M. Manufacture and mechanical properties of self-bonded boards from kenaf core. J. Wood Sci. 2004, 50, 53-61. [CrossRef]

22. Chow, S. Bark boards without synthetic resins. Forest Prod. J. 1974, 25, 32-37.

23. Wang, J.; Liu, J.; Ni, L.; Li, J. Thermopressed binderless fiberboards from wheat straw by adding black liquor. Wood Res. 2018, 63, 1021-1032.

24. Rastegarfar, N.; Behrooz, R.; Bahramifar, N. Electrocoagulation treatment of black liquor from soda-AQ pulping of wheat straw. Environ. Monit. Assess. 2015, 187, 1-9. [CrossRef]

25. Ghatak, H.R.; Kumar, S.; Kundu, P.P. Electrode processes in black liquor electrolysis and their significance for hydrogen production. Int. J. Hydrogen Energ. 2008, 33, 2904-2911. [CrossRef]

26. Geng, X.; Deng, J.; Zhang, S. Paper mill sludge as a component of wood adhesive formulation. Holzforschung 2007, 61, 688-692. [CrossRef]

27. Larson, E.D.; Consonni, S.; Katofsk, R.E.; Frederic, W.J.A. Cost-Benefit Assessment of Gasification-Based Biorefining in the Kraft Pulp and Paper Industry; American Forest and Paper Association: Washington, DC, USA, 2006.

28. Wang, K. The Timber Industry Practical Encyclopedia (Fiberboards); China Forestry Press: Beijing, China, 2002.

29. GB/T 742-2008 Fibrous Raw Material, Pulp, Paper and Board-Determination of Ash; Inspection and Quarantine of the People's Republic of China/Standardization Administration of the People's Republic of China: Beijing, China, 2008.

30. GB/T 2677.4-1993 Fibrous Raw Material-Determination of Water Solubility; Inspection and Quarantine of the People's Republic of China/Standardization Administration of the People's Republic of China: Beijing, China, 1993.

31. GB/T 2677.5-1993 Fibrous Raw Material-Determination of one Percent Sodium Hydroxide Solubility; Inspection and Quarantine of the People's Republic of China/Standardization Administration of the People's Republic of China: Beijing, China, 1993.

32. GB/T 10741-2008 Pulps-Determination of Alcohol-Benzene Solubles; Inspection and Quarantine of the People's Republic of China/Standardization Administration of the People's Republic of China: Beijing, China, 2008.

33. GB/T 747-2003 Pulps-Determination of Acid-Insoluble Lignin; Inspection and Quarantine of the People's Republic of China/Standardization Administration of the People's Republic of China: Beijing, China, 2003.

34. Waddle, W.J. A simple ultraviolet spectrophotometric method for the determination of protein. J. Lab Clin. Med. 1956, 48, 311. 
35. GB/T 17657-2013 Test Methods of Evaluating the Properties of Wood-Based Panels and Surface Decorated Wood-Based Panels; Inspection and Quarantine of the People's Republic of China/Standardization Administration of the People's Republic of China: Beijing, China, 2013.

36. Bekhta, P.; Niemz, P.; Sedliacik, J. Effect of pre-pressing of veneer on the glueability and properties of veneer-based products. Eur. J. Wood Wood Prod. 2012, 70, 99-106. [CrossRef]

37. de Cademartori, P.H.G.; Missio, A.L.; Mattos, B.D.; Schneid, E.; Gatto, D.A. Physical and mechanical properties and color changes of fast-growing Gympie messmate wood subjected to two-step steam-heat treatments. Wood Mat. Sci. Eng. 2014, 9, 40-48. [CrossRef]

38. Bekhta, P.; Niemz, P. Effect of high temperature on the change in color, dimensional stability and mechanical propertied of stability and mechanical properties of spruce wood. Holzforschung 2003, 57, 539-546. [CrossRef]

39. Araújo Junior, C.P.; Coaquira, C.A.C.; Mattos, A.L.A.; de Souza Filho, M.d.S.M.; de Andrade Feitosa, J.P.; de Morais, J.P.S.; de Fitas Rosa, M. Binderless fiberboards made from unripe coconut husks. Waste Biomass Valoriz. 2018, 9, 2245-2254. [CrossRef]

40. Hashim, R.; Saari, N.; Sulaiman, O.; Sugimoto, T.; Hiziroglu, S.; Sato, M.; Tanaka, R. Effect of particle geometry on the properties of binderless particleboard manufactured from oil palm trunk. Mater. Design 2010, 31, 4251-4257. [CrossRef]

41. Migneault, S.; Koubaa, A.; Riedl, B.; Nadji, H.; Deng, J.; Zhang, S.Y. Binderless fiberboard made from primary and secondary pulp and paper sludge. Wood Fiber Sci. 2011, 43, 180-193.

42. Mancera, C.; Ferrando, F.; Salvado, J.; El Mansouri, N.E. Kraft lignin behavior during reaction in an alkaline medium. Biomass Bioenerg. 2011, 35, 2072-2079. [CrossRef]

43. Pizzi, A.; Mittal, K.L. Handbook of Adhesive Technology; CRC Press: Boca Raton, FL, USA, 2003.

44. Rowell, R.M. Handbook of Chemistry and Wood Composites; CRC Press: Boca Raton, FL, USA, 2005.

45. Zhu, H.; Li, Y.; Pettersson, B.; Zhang, L.; Lindström, M.; Henriksson, G. Technical soda lignin dissolved in urea as an environmental friendly binder in wood fiberboard. J. Adhes. Sci. Technol. 2014, 28, 490-498. [CrossRef]

46. Olsen, P.O.; Plackett, D.V. Perspectives on the performance of natural plant fibers presented at natural fibres performance forum. Copenhagen 1999, 5, 27-28.

47. George, W.O.; McIntyre, P.S. Infrared Spectroscopy: Analytical Chemistry by Open Learning; John Wiley and Sons Inc.: London, UK, 1987.

48. Abdul Khalil, H.P.S.; Nur Firdaus, M.Y.; Jawaid, M.; Anis, M.; Ridzuan, R.; Mohamed, A.R. Development and material properties of new hybrid medium density fiberboard from empty fruit bunch and rubberwood. Mater. Design 2010, 31, 4229-4236. [CrossRef]

49. Velasquez, J.A.; Ferrando, F.; Salvado, J. Binderless fiberboard from steam exploded Miscanthus sinensis: The effect of a grinding process. Holz Roh. Werkst. 2002, 60, 297-302. [CrossRef]

50. Velasquez, J.A.; Ferrando, F.; Salvado, J. Effects of kraft lignin addition in the production of binderless fiberboard from steam exploded Miscanthus sinensis. Ind. Crop. Prod. 2003, 18, 17-23. [CrossRef]

51. Van Dam, J.E.G.; van den Oever, M.J.A.; Teunissen, W.; Keijsers, E.R.P.; Peralta, A.G. Process for production of high density/high performance binderless boards from whole coconut husk. Part 1: Lignin as intrinsic thermosetting binder resin. Ind. Crop. Prod. 2004, 19, 207-216. [CrossRef]

52. Colom, X.; Carrillo, F.; Nogues, F.; Garriga, P. Structural analysis of photodegraded woodby means of FTIR spectroscopy. Polym. Degrad. Stabil. 2003, 80, 543-549. [CrossRef]

53. Haris, P.I.; Chapman, D. Analysis of polypeptide and protein structures using Fourier transform infrared spectroscopy. In Methods Molecular Biology: Microscopy, Optical Spectroscopy, and Macroscopic Techniques; Humana Press: Totowa, NJ, USA, 1994.

54. Lee, N.; Kwon, O.J.; Chun, B.C.; Park, J.S. Characterization of castor oil/polycaprolactone polyurethane biocomposites reinforced with hemp fibers. Fibers Polym. 2009, 10, 154-160. [CrossRef]

55. Hakkou, M.; Pétrissans, M.; Gérardin, P.; Zoulalian, A. Investigations of the reasons for fungal durability of heat-treated beech wood. Polym. Degrad. Stab. 2006, 91, 393-397. [CrossRef]

56. Goring, D.A.I. Thermal softening of lignin, hemicellulose and cellulose. Pulp Paper Mag. Can. 1963, 64, 517-527.

57. Bouajila, J.; Limare, A.; Joly, C.; Dole, P. Lignin plasticization to improve binderless fiberboard mechanical properties. Polym. Eng. Sci. 2005, 45, 809-816. [CrossRef] 
58. Forest Products Laboratory. Wood Handbook. Wood as an Engineering Material; General Technical Report FPL-GTR-190; US Department of Agriculture, Forest Service, Forest Products Laboratory: Madison, WI, USA, 2010.

59. GB/T 21723-2008 Wheat/Rice-Straw Particleboard; Inspection and Quarantine of the People's Republic of China/Standardization Administration of the People's Republic of China: Beijing, China, 2008.

60. Luo, P.; Yang, C. Self-bonded particleboard from steam exploded wheat straw. In Advanced Materials Research; Trans Tech Publications: Zürich, Switzerland, 2011.

(c)

(C) 2019 by the authors. Licensee MDPI, Basel, Switzerland. This article is an open access article distributed under the terms and conditions of the Creative Commons Attribution (CC BY) license (http://creativecommons.org/licenses/by/4.0/). 